\title{
A Development of Kansei Words for Robotic Therapy and the Elderly
}

\author{
Saiful Azman Bidin, Anitawati Mohd Lokman, Wan Abdul Rahim Wan Mohd Isa,
}

Faculty of Computer and Mathematical Sciences, Universiti Teknologi MARA (UiTM), Shah Alam, Selangor, Malaysia

saifulazman@gmail.com, anitawatix@uitm.edu.my,wrahim2@tmsk.uit.edu.my

Tel of 1st Author: +603-55211208

\begin{abstract}
Age has physical and psychological effects. Mental or emotional access is more difficult. It is easily effected and can lead to suicide. Despite limited attention and solutions, robotic therapy has given the elderly new hope. The learning environment is used to stimulate positive emotion while interacting with robots. It has grown in popularity as a potential benefit for the elderly to improve their health and social consequences. The goal is to create a list of emotion keywords or Kansei Words that can be used in robotic learning therapy design. These findings lay the groundwork for future research on elderly Kansei Robotic therapy.
\end{abstract}

Keywords: Ageing, Elderly, Emotion, Kansei Robotic, Robot Therapy, Human-Robot Interaction, Interaction Design,

eISSN: 2398-4287 ( 2021. The Authors. Published for AMER ABRA cE-Bs by e-International Publishing House, Ltd., UK. This is an open access article under the CC BYNC-ND license (http://creativecommons.org/licenses/by-nc-nd/4.0/). Peer-review under responsibility of AMER (Association of Malaysian Environment-Behaviour Researchers), ABRA (Association of Behavioural Researchers on Asians) and cE-Bs (Centre for Environment-Behaviour Studies), Faculty of Architecture, Planning and Surveying, Universiti Teknologi MARA, Malaysia.

DOI: https://doi.org/10.21834/ebpj.v6iSI5.2930

\subsection{Introduction}

Even though growing old is a normal process of life, the old adult could receive some side effects from the ageing process. The impact of the problem can affect both physically and psychologically, which is related to emotion. This psychology and emotion aspect is more difficult to access and cannot be seen clearly as compared to the physical aspect. The problem is related to the perception of emotion such as feeling lonely or disappointed or even anger by showing expression through faces and vocal (World Health Organization, and Unicef., 2015). Depression disorder is a common ageing issue for the elderly as they experience difficult time such as loss of social roles, loss of a family member and loss of physical function (El-Gilany et al,2018). It may cause an adverse effect that can lead to suicide if no therapy is performed to the patient (Alexopoulos, 2005)

This situation could become even more worrying if the elderly population keep consistently increasing every year all over the world. The number of older populations is expected to increase by 15 per cent in 2030, and a majority of old people aged over 80 will be living alone by themselves (Bidin, Lokman and Isa, 2018). The ageing impact will grow wider and affect the elderly around the world if there are no or little attempts are given for serious solutions. Recently, robotic intervention has been introduced by research to fill the need which mainly aim to heal the elderly emotional sore by focusing on relieving patient from psychological or emotion failure. As such, this research will be focusing on robotic therapy based on learning.

As reference by (Dewey et al, 2002) prescribed that the learning process can keep our brain active by involving cognitive activity that can influence user's feeling for better emotion wellness. Thus, robotic therapy was used to stimulate people's feeling of positive emotion while they interact with the robot.

Despite the emerging research on the intervention of robotic in the learning system, there is very less study in robotic learning study for elderly for their therapy (Bidin et al, 2017; Shamsuddin, 2013). Therefore, striving to provide an alternative solution for elderly emotion therapy, and also to produce a ground knowledge basis for future work in developing Kansei robotic therapy for the elderly, the research

eISSN: 2398-4287 ( 2021. The Authors. Published for AMER ABRA cE-Bs by e-International Publishing House, Ltd., UK. This is an open access article under the CC BYNC-ND license (http://creativecommons.org/licenses/by-nc-nd/4.0/). Peer-review under responsibility of AMER (Association of Malaysian Environment-Behaviour Researchers), ABRA (Association of Behavioural Researchers on Asians) and cE-Bs (Centre for Environment-Behaviour Studies), Faculty of Architecture, Planning and Surveying, Universiti Teknologi MARA, Malaysia.

DOI: https://doi.org/10.21834/ebpj.v6iSI5.2930 
as reported in this paper investigate and identify all possible emotion keywords that related to elderly learning by using robotic learning. The next section elaborates details on Kansei Words, the research procedure and the result.

\subsection{Synthesize Kansei Words}

Kansei Engineering methodology plays a great catalyst for a systematical development of new and innovative solutions based on emotion and design. It can also be used as an improvement tool for existing products or concepts. The methodology was invented by Professor Mitsuo Nagamachi, an emeritus professor of Hiroshima University, and the founder of International Kansei Design Institute, Japan. Kansei Engineering is derived from the Japanese word Kansei kougaku which means "consumer's psychological feeling and image" (Nagamachi and Lokman, 2015). Currently, the Kansei Engineering methodology is well recognized, published and used widely around the globe.

Kansei Engineering is based on subjective estimations of product and concept properties and discovers associated emotion to the demands on the products. It translates users' impressions, feelings and demands on existing products or concepts into design solutions and parameters that fulfil the user's feeling requirement (Lokman, 2010). Despite of many other methods such as Quality Function Deployment (QFD), Conjoint Analysis, and Voice of Customer which have similar aims, the major significant advantage of and Kansei Engineering from other methods is it's specialized on determining user's implicit desire and link it with product or service design characteristic (Lokman, 2010). One of the procedures in Kansei Engineering is to measure user's implicit emotional reaction. While it is implicit, the assessment process can be very challenging and interesting.

There are several techniques of emotion assessment that can be used to translate implicit emotion into a verbal description. It could be done by the use of animation, pulse detection, face expression, self-reporting, observation and others (Nagamachi, 1999). The use of emotional key words is the easiest way to translate user's emotion. In Kansei engineering, the emotional keywords are called Kansei Words. Kansei Words can be an adjective word or a short sentence that is used to represent emotional impression towards a product, situation or surrounding (Nagamachi, 1999). The process of synthesizing Kansei Words consists of exploring related emotional keywords from pertinent resources, refine and validate the keywords.

The first step is to gather full range of emotional keywords, and for this process, Lokman (2010) suggested to include every possible keyword. The emotional keywords can be synthesized using many ways such as brain-storming, from experts, analyzing technical documents, magazines or guidebook, and analyzing pertinent literatures, to identify words expressing sensibility and emotions (Nagamachi, 2008).

As stated on (Lokman, 2010; Nagamachi and Lokman,2010; Lokman and Kamaruddin, 2010), those words need to be refined and validated after the synthesis process are done, the refining process is to assess the words to check the accuracy of the words to represent certain domain and make comparison with thesaurus and glossary. Redundancy or inaccuracy will be eliminated excluded. For the validation process, the resulting set of words from the earlier process will be assessed by experts or representative of targeted respondents. In this process, either a qualitative or quantitative approach could be used.

In this research case, the Kansei words were first identified from past literature related to robotic and the elderly. The words were then refined and verified by three language experts. Every language expert has a Master degree in English language and at least two years teaching and learning experiences. All the experts were communicated via email and they were briefed to add refinement when needed and verify all the words that are suitable to describe robotic learning and the elderly emotion state. This requirement was specified to make sure the Kansei Words list is accurate to represent the elderly emotion in robotic learning therapy. Table 1 shows the list of the expert with their qualification and teaching experience.

Table 1. The language expert list

\begin{tabular}{lll}
\hline Language Experts & Qualification & $\begin{array}{l}\text { Teaching and Learning } \\
\text { Experiences }\end{array}$ \\
\hline Expert 1 & $\begin{array}{l}\text { Bachelor of Translation } \\
\text { and Interpretation } \\
\text { (USM), M.TESL(UPM) }\end{array}$ & 4 \\
Expert 2 & $\begin{array}{l}\text { M.A (English Literature) } \\
\text { Sheffield University, UK }\end{array}$ & 3 \\
Expert 3 & M.TESL (UPM) & 4 \\
\hline
\end{tabular}




\subsection{Result and Discussion}

As illustrated on table 2, the process for synthesizing kansei words can be summarized as below. The process can be divided into three phase of activity and deliverables.

Table 2. The Process for synthesizing Kansei Words

\begin{tabular}{|c|c|c|}
\hline Phase & Activity / Process & Deliverables \\
\hline Phase 1 & $\begin{array}{l}\text { Identify emotional } \\
\text { keywords from journals, } \\
\text { article, thesis paper and } \\
\text { proceeding paper related } \\
\text { to robotic and the elderly. }\end{array}$ & Initial emotional keywords \\
\hline Phase 2 & $\begin{array}{l}\text { Compare the emotional } \\
\text { keywords with thesaurus } \\
\text { and glossary }\end{array}$ & $\begin{array}{l}64 \text { refined emotional } \\
\text { keywords }\end{array}$ \\
\hline Phase 3 & $\begin{array}{l}\text { Verifying the emotion } \\
\text { words with languages } \\
\text { experts }\end{array}$ & $\begin{array}{l}48 \text { verified emotional } \\
\text { keywords }\end{array}$ \\
\hline
\end{tabular}

As a result, from the first process, there are 64 emotion keywords identified to be related to robotic and the elderly. After verification by three language expert, the number of emotion keywords is reduced to 48 emotion keywords. Those words can be retrieved on table 3 as below.

Table 3 shows the process and resulting Kansei Words list.

Table 3. The result of Kansei Words

\begin{tabular}{|c|c|c|c|}
\hline $\begin{array}{l}\text { Emotional Key Words from the multiple resources } \\
\text { search }\end{array}$ & $\begin{array}{l}\text { Refining and Verify by } \\
\text { Language Expert } 1\end{array}$ & $\begin{array}{l}\text { Refining and Verify by } \\
\text { Language Expert } 2\end{array}$ & $\begin{array}{l}\text { Refining and Verify by } \\
\text { Language Expert } 3\end{array}$ \\
\hline $\begin{array}{l}\text { Comfortable, Familiar, Interesting, Curious, Happy, } \\
\text { Uncanny, Secure, Meaningful, Easy, Pleasurable, } \\
\text { Simple, Useful, Safe, Closer, smooth, undreadful, Fast, } \\
\text { Usefulness, Favorable, Moderate, Calm, Confident, } \\
\text { Peaceful, Convenient, Relieved, Warm, Relaxing, Fine, } \\
\text { Loving, Amused, Courtesy, Thankful, Patient, Sincere, } \\
\text { Humble, Cheerful, Joyful, Lively, Positive, Playful, Jolly, } \\
\text { Wonderful, Celebrated, Enjoyable, Carefree, Fantastic, } \\
\text { Exciting, Smart, Creative, Optimistic, Adorable, Ace, } \\
\text { Lucky, Grateful, Fun, Complacent, Blissful, Blessed } \\
\text { Gratifying, Hopeful, Pleasant, Satisfied, Plenty, } \\
\text { Contented, }\end{array}$ & $\begin{array}{l}\text { Comfortable, Familiar } \\
\text { Interesting, Curious } \\
\text { Happy, Uncanny } \\
\text { Secure, Meaningful } \\
\text { Easy, Pleasurable } \\
\text { Simple, Useful, Safe, } \\
\text { Smooth, Fast, Calm } \\
\text {, Favorable, Moderate } \\
\text { Confident, Peaceful } \\
\text { Convenient, Relieved } \\
\text { Warm, Relaxing } \\
\text { Fine, Loving, Amused } \\
\text { Thankful, Patient } \\
\text { Sincere, Humble } \\
\text { Cheerful, Lively } \\
\text { Positive, Playful } \\
\text { Wonderful, } \\
\text { Celebrated } \\
\text { Enjoyable, Carefree } \\
\text { Fantastic, Exciting } \\
\text { Smart, Creative } \\
\text { Optimistic, Adorable } \\
\text { Gratifying, Hopeful } \\
\text { Pleasant, Satisfied } \\
\text { Contented, } \\
\text { Complacent } \\
\text { Blissful, Blessed, } \\
\text { Lucky, Grateful, Fun }\end{array}$ & $\begin{array}{l}\text { Comfortable, Familiar } \\
\text { Interesting, Happy } \\
\text { Secure, Meaningful } \\
\text { Easy, Simple, Useful } \\
\text { Safe, Closer, Smooth } \\
\text { Fast, Usefulness } \\
\text { Favorable, Moderate } \\
\text { Calm, Confident } \\
\text { Peaceful, Convenient } \\
\text { Relieved, Warm } \\
\text { Relaxing, Fine, } \\
\text { Loving } \\
\text { Amused, Courtesy } \\
\text { Thankful, Patient } \\
\text { Sincere, Humble } \\
\text { Cheerful, Joyful } \\
\text { Lively, Positive } \\
\text { Satisfied, Plenty } \\
\text { Contented, } \\
\text { Complacent } \\
\text { Blissful, Blessed, } \\
\text { Lucky } \\
\text { Grateful, Fun }\end{array}$ & $\begin{array}{l}\text { Comfortable, Familiar } \\
\text { Interesting, Happy } \\
\text { Secure, Meaningful } \\
\text { Easy, Simple, Useful } \\
\text { Safe, Smooth, Fast } \\
\text { Favorable, Moderate } \\
\text { Calm, Confident } \\
\text { Peaceful, Convenient } \\
\text { Relieved, Warm } \\
\text { Relaxing, Fine, } \\
\text { Loving } \\
\text { Amused, Thankful } \\
\text { Patient, Sincere, } \\
\text { Humble } \\
\text { Cheerful, Lively, } \\
\text { Positive Playful, } \\
\text { Wonderful, Carefree, } \\
\text { Fantastic, Exciting, } \\
\text { Smart } \\
\text { Creative, Hopeful, } \\
\text { Pleasant } \\
\text { Satisfied, Contented, } \\
\text { Complacent, Blissful, } \\
\text { Blessed, Lucky } \\
\text { Grateful, Fun }\end{array}$ \\
\hline
\end{tabular}

However, the resulting emotional keywords is quite too many. These words may have redundancy in meanings and cause vagueness in future Kansei evaluation process. As mentioned by (Lokman, 2013; Nagamachi and Lokman,2010; Lokman and 
Kamaruddin, 2010), the huge data resulting from too many and vague emotional keywords may affect poor data quality during the analysis process and will affect the overall result. They could be used as is, but it could give a poor result and create vague assumptions. At the same time, it could be difficult for the elderly as they might need to do self-reporting during the evaluation phase, as they are already facing challenges physically and emotionally due to ageing.

Thus, reference by (Lokman, 2013; Nagamachi and Lokman,2010) had suggested that it is highly recommended to reduce the number of Kansei Word so that it can produce the most significant and accurate resources for the evaluation process. There are many methods to resize the number of Kansei Words such as a manual selection of the Kansei word list by domain expert, (Nagamachi and Lokman,2010) semantic differential ratings, and regression analysis (Lokman and Kamaruddin, 2010).

Other solutions that can be used is the Affinity diagram performed based on the KJ method. The participants will brainstorm all the Kansei Words that might be used to illustrate the particular artefacts and then manually classify them into certain affinity before concluding a representative emotional keyword on their cluster (Lokman and Kamaruddin, 2010). Hence, the work will proceed to the next level of reducing the number of emotional keywords in the future.

\subsection{Conclusion}

Each discussion made in above sections is important to robotic learning therapy for the elderly against ageing impact. The resulting robotic and elderly specific Kansei Words list could become a significant reference in order to get know and understand the elderly's emotional impression that will later be translated into new robotic learning therapy design that fits their needs (Bidin and Lokman,2018).

Nevertheless, further study needs to be conducted to validate the Kansei Words list with the elderly expert, robotic expert and interaction design expert. This process is important in order to make sure the list is suitable with the elderly emotion characteristic requirement that is targeted to evoke motivation and prescription to the designers in designing an interaction for elderly teaching and learning as well as their solution to gain a successful emotion wellness therapy.

\section{Acknowledgements}

The paper is supported by Universiti Teknologi MARA (UiTM) under its BESTARI grant scheme (No.: 600-IRMI/PERDANA 5/3 BESTARI (094/2018). The authors gratefully acknowledge Malaysian Ministry of Higher Education (MoHE), the Research Initiative Group of Kansei/Affective Engineering (RIG KAE), Faculty of Computer and Mathematics Sciences, Universiti Teknologi MARA (UiTM), Shah Alam, Selangor, Malaysia and the Malaysia Association of Kansei Engineering (MAKE) for their support.

\section{References}

Alexopoulos, G. S. (2005). Depression in the elderly. The lancet, 365(9475), 1961-1970.

Bidin, S. A. H., Taharim, N. F., Lokman, A. M., and Isa, W. A. R. W. M. (2018, March). Empowering Elderly Emotion Wellness using Cultural Kansei Robotic Interaction Design. In International Conference on Kansei Engineering and Emotion Research (pp. 554-563). Springer, Singapore.

Bidin, S. A. H., and Lokman, A. M. (2018). Enriching the comfortability emotion on website interface design using kansei engineering approach. In International Conference on Kansei Engineering and Emotion Research (pp. 792-800). Springer, Singapore.

Bidin, S. A. H., Lokman, A. M., Mohd, W. A. R. W., and Tsuchiya, T. (2017). Initial intervention study of kansei robotic implementation for elderly. Procedia Comput Sci, $105,87-92$.

Dahlgaard, J. J., and Nagamachi, M. (2008). Perspectives and the new trend of Kansei/affective engineering. The TQM Journal.

Dewey, D., Kaplan, B.J., Crawford, S.G., Wilson, B.N. (2002). Developmental coordination disorder: associated problems in attention, learning, and psychosocial adjustment. Human movement science, 21(5), pp.905-918.

El-Gilany, A. H., Elkhawaga, G. O., and Sarraf, B. B. (2018). Depression and its associated factors among elderly: A community-based study in Egypt. Archives of gerontology and geriatrics, 77, 103-107.

Lokman, A. M. (2013, November). KE as affective design methodology. In 2013 International Conference on Computer, Control, Informatics and Its Applications (IC3INA) (pp. 7-13). IEEE.

Lokman, A. M. (2010). Design and emotion: The kansei engineering methodology. Malaysian Journal of Computing, 1(1), 1-11.

Lokman, A. M., and Kamaruddin, K. A. (2010). Kansei affinity cluster for affective product design. In 2010 International Conference on User Science and Engineering (iUSEr) (pp. 38-43). IEEE.

Nagamachi M., Lokman, A.M. (2015). Kansei Innovation: Practical Design Applications for Product and Service Development. Taylor and Francis

Nagamachi M., Lokman, A.M. (2010). Innovations of Kansei Engineering. Industrial Innovation Series. Adedeji B. Badiru (Eds.). Taylor and Francis.

Nagamachi, M. (1999, October). Kansei engineering: the implication and applications to product development. In IEEE SMC'99 Conference Proceedings. 1999 IEEE International Conference on Systems, Man, and Cybernetics (Cat. No. 99CH37028) (Vol. 6, pp. 273-278). IEEE 
Shamsuddin, S., Malik, N.A., Hashim, H., Yussof, H., Hanapiah, F.A. and Mohamed, S. (2013). Robots as adjunct therapy: Reflections and suggestions in rehabilitation for people with cognitive impairments. In: FIRA RoboWorld Congress (pp. 390-404). Springer, Berlin, Heidelberg.

World Health Organization, and Unicef. (2015). Trends in maternal Mortality: 1990-2015: Estimates from WHO, UNICEF, UNFPA, World Bank Group and the United Nations Population Division. 